\title{
Beşinci Sınıf Öğrencilerinin Çarpma ve Bölme İşlemine Yönelik Kurdukları Problemlerin Analizi * Muhammet DORUK $^{* *}$, Gül DORUK ${ }^{* * *}$
}

Öz: Bu çalışmanın amacı ortaokul beşinci sınıf öğrencilerinin çarpma ve bölme işlemine yönelik kurdukları problemlerin ve bu işlemlere yükledikleri anlamların özelliklerini ortaya çıkarmaktır. Çalışmanın araştırma grubunu 2017-2018 eğitim öğretim yılında, Türkiye’nin Doğu Anadolu Bölgesi'nde yer alan bir ilin devlet ortaokulunda öğrenim gören toplam 95 beşinci sınıf öğrencisi oluşturmaktadır. Araştırma nitel araştırma yaklaşımının benimsendiği bir durum çalışması örneğidir. Çalışmanın verileri, öğrencilerin çarpma ve bölme işlemine yönelik kurdukları yapılandırılmış problemlerden ve 12 öğrenciyle yapılan yarı yapılandırılmış görüşmelerden elde edilmiştir. Çalışma sonucunda öğrencilerin çarpma işlemi için kurdukları problemlerde en çok ölçeklendirme yapısının, bölme işlemi için ise eşit paylaştırma yapısının tercih edildiği ortaya çıkmıştır. Öğrencilerin çarpma ve bölme işlemiyle ilgili problem kurma konusunda birçok güçlüğe sahip oldukları ortaya çıkmıştır. Öğrencilerin problem kurmada sahip oldukları güçlüklerin başında işlemleri gerçek hayat ile ilişkilendirme güçlüğü yer almıştır. Ayrıca öğrencilerin farklı işlemlere yönelik problem kurdukları, ilişkisiz veriler kullandıkları, soru cümlesi yazamadıkları ve bölme işlemi için eksik veya fazla paylaşım yaptıkları tespit edilmiştir. Yapılan görüşmeler sonucunda, tespit edilen güçlüklerin öğrencilerin çarpma ve bölme işlemine yönelik doğru bir anlayışa sahip olamamalarından ve

\footnotetext{
* Bu araştırmanın bir kısmı 27. Uluslararası Eğitim Bilimleri Kongresi’nde sözlü bildiri olarak sunulmuştur.

** Dr. Öğr. Üyesi Hakkari Üniversitesi, Eğitim Fakültesi, Matematik Eğitimi Anabilim Dalı, mdoruk20@gmail.com, https://orcid.org/0000-0003-3085-1706

*** Öğretmen Hakkari Şehit Selahattin Ortaokulu, gulaslan3536@gmail.com, https://orcid.org/0000-0003-2558$\underline{3719}$
}

Gönderim:22.06.2019 Kabul:09.08.2019 $\quad$ Yayın: 30.09.2019


işlemlere gerçek hayatla bağlantılı olmayan anlamlar yüklemelerinden kaynaklanabileceği düşünülmüştür.

Anahtar Kelimeler: Problem kurma, çarpma, bölme, matematik eğitimi.

\section{Analysis of the Problems Posed by the Fifth Grade Students Related to Multiplication and Division}

Abstract: The aim of this study is to reveal the characteristics of the problems posed by fifth grade middle school students for the multiplication and division operations and the meanings loaded by them to these operations. The research group of the study consisted of 95 fifth-year students studying in the state middle school of a province in the Eastern Anatolia Region of Turkey in 2017-2018 academic year. The study based on qualitative research approach was an example of a case study. The data of the study was obtained from the structured problems posed by the students for multiplication and division operations and semi-structured interviews with 12 students. As a result of the study, it was revealed that the scaling for multiplication and the equal sharing for division were the most preferred structures by the students. It emerged that students had many difficulties in problem posing with the multiplication and division operations. Students mostly had difficulty in associating operations with real life. It was also determined that students posed problems for different operations, used unrelated data, could not write question phrase, done less or more sharing for division. As a result of the interviews, it was thought that the detected difficulties might be emerged from students' improper understandings of multiplication and division operations and being loaded meanings of operations unrelated with real life.

Keywords: Problem posing, multiplication, division, mathematics education.

\section{Giriş}

Problem kavramının sözlük anlamı: sorun, teoremler ve kurallar yardımıyla çözülmesi istenen soru veya mesele şeklindedir (Türk Dil Kurumu [TDK], 2015). Sözlük tanımında problemin çözülmesi gereken bir sorun olduğu ve mevcut bilgilerle çözülebilecek bir yapıda olması gerektiği vurgulanmaktadır. Problem kavramının matematik eğitimi araştırmacıları tarafından genel kabul gören özellikleri olmakla birlikte, ortak kullanılan bir tanımı yoktur. Hiebert ve diğerleri (1997) problemi, herhangi bir görevin çözümü için öğrencilerin daha 
önceden ne bildikleri ya da ezberledikleri kural ya da yöntemin olduğu, ne de öğrencilerle belirlenmiş bir doğru çözüm metodunun olduğu algısının bulunmadığı bir durum olarak tanımlamıştır (Akt. Van de Walle, Karp ve Bay-Williams, 2013). Türnüklü ve Yeşildere (2005) problemi bir sorun olarak tanımlayarak, problemde çözme isteği uyandırma, ilk defa karşılaşma, standart bir çözüm yolu bulunmama, kişinin bilgi birikimiyle çözülebilme özelliklerinin olduğunu belirtmiştir. Olkun ve Toluk'un (2014) problem tanımında problemin çözümü hazır olmamalı, kişinin mevcut bilgileri ile çözülebilir olmalı ve kişide çözme isteği uyandırmalıdır. Benzer şekilde Altun (2014a) problemin kişi için bir güçlük olma, kişinin çözüme ihtiyaç duyma ve problem durumu ile daha önce karşılaşmamış olma özelliklerini taşıması gerektiğini belirtmiştir. $\mathrm{Bu}$ tanımlara göre bir sorunun problem olarak değerlendirilmesinde öznel kriterler mevcuttur. Problem durumunun daha önce karşılaşılmamış ve kişi için bir güçlük oluşturması gerekir (Baykul, 2014). Bu bağlamda bir kişi için problem olan bir durum başkası için problem olmayabilir (Altun, 2014b). Aynı soruyu içeren problem, bir öğrenci için alıştırma başka bir öğrenci için ise çözülemez olabilir (Baki, 2014).

Problemin çözümü süreci, net olarak tasarlanan fakat hemen sonuca ulaşılamayan bir hedefe ulaşmak için kontrollü etkinliklerle araştırma yapmaktır (Altun, 2014b). Bu durum problem çözmenin sadece bir sonuç olmadığını, belirli aşamaları olan bir süreç olduğunu göstermektedir (Sezgin, 2011). Problem çözme konusunda en çok kabul gören süreç Polya'nın (1945) dört aşamalı sürecidir (Altun, 2014b). Bu aşamalar: problemi tanıma, çözüm için plan hazırlama, planın uygulanması ve değerlendirme olarak isimlendirilmiştir (Baki, 2014). Problem çözme sürecinde kullanılan başlıca stratejiler ise: sistematik liste yapma, tahmin ve kontrol, diyagram çizme, bağıntı bulma, eşitlik yazma, tahmin etme, benzer problemlerin çözümünden faydalanma, geriye doğru çalışma, tablo yapma ve muhakeme etmedir (Altun, 2014b). Baykul (2014) problem çözmeyi öğrenmenin, öğrencilerin problem çözmede kendi stratejilerini geliştirmesiyle mümkün olacağını belirtmiştir. Baykul (2014), Altun'un (2014b) belirttiği stratejilerden farklı olarak: matematik cümlesi yazma, rol yapma, modelleri kullanma, yapılardan yararlanma, basitleştirme ve küçük parçalara ayırma stratejilerini ifade etmiştir. Problem çözme adımlarından değerlendirme aşamasında öğrencilerden yaptıkları çözümün doğruluğunu ve farklı çözüm yollarını araştırmasının yanında, öğrencilerden problemi farklı şekillerde ifade etmeleri ve 
çözümün nasıl olacağını düşünmeleri istenmektedir (Altun, 2014b; Baki, 2014). Diğer bir deyişle, öğrencilerden verilen duruma uygun problem kurmaları istenmektedir. Problem kurma çalışmalarının iki büyük önemi vardır. Birincisi öğrencilerin problem durumunu kendilerinin ifade etmek zorunda kalması diğeri ise problem kurma ile problem çözme arasında güçlü bir ilişkinin olmasıdır (Altun, 2014b). Problem kurma, problem çözmenin beşinci aşaması (Gonzales, 1998) ve problem çözmenin basamaklarından sonra gerçekleşmesi gereken bir süreç (Millî Eğitim Bakanlığı [MEB], 2018) olarak değerlendirilmiştir. Problem çözmeyi öğretme-öğrenme sürecinde Polya'nın (1945) dört aşamasına ek olarak problem kurma çalışmaları beşinci aşama olarak ifade edilmiştir (Baykul, 2014).

Problem tanımı ile benzer olarak, matematik eğitimi araştırmacıları problem kurma kavramını farklı şekillerde tanımlamışlardır. Yapılan tanımlamalarda problem kurma: verilen bir durum/problemden yola çıkarak yeni problemler oluşturma (Akay, 2006; Dede ve Yaman, 2005; Silver, 1994; Tichá ve Hošpesová, 2009) ya da verilen durum/problem üzerinde değişiklikler yaparak problem üretme (Akay, Soybaş ve Argün, 2006; Dinç, 2018; Silver, 1994; Tichá ve Hošpesová, 2009) anlamında kullanılmaktadır. Problem kurma, verilen bir problemi yeniden düzenleme, çözümü verilen problemi yazma ya da bir grafik, resim gibi görsel üzerinden problem oluşturularak gerçekleştirilen etkinliklerdir (Dinç, 2018). Gerçek yaşamdan alınan durumların matematiksel olarak anlamlı problemlere dönüştügü bir süreçtir (Stoyanova ve Ellerton 1996). Problem çözme ile yakından ilişkili olan problem kurma, problem çözmenin daha ileri adımıdır ve problem çözmeyi de içermektedir (Bonotto ve Dal Santo, 2015). Problem çözmeye göre daha karmaşık ve üst düzey düşünme becerisi gerektirir (Bunar, 2011).

Öğrencilerin problem çözme becerisini geliştirmek matematiğin en önemli amaçlarından biridir. Son zamanlarda ise öğrencilerin sadece problem çözebilen değil bunun yanında problem kurabilen bireyler olması amaçlanmaktadır (Dinç, 2018). Öğrenciler kurdukları matematiksel problemler sayesinde problemin matematiksel anlamını, sahip oldukları becerileri ve tutumları yansıtırlar (Toluk-Uçar, 2009). Bu çerçeveden bakıldığında problem kurma aktiviteleri yardımıyla öğrencilerin öğrenme çıktıları değerlendirilebilir, kavramsal anlayışları, hata ve kavram yanılgıları tespit edilebilir (Işık ve Kar, 2015). Bu 
nedenle problem kurma öğrencilerin matematiğe yönelik anlayışlarını ortaya çıkarmaya yarayan bir araçtır (Stoyanova, 2003).

Problem kurma aktiviteleri problem çözme becerisi başta olmak üzere (English 1998; Fidan, 2008; Silver, 1994), öğrencilerin matematiksel kavramları daha iyi anlamalarına (Dickerson, 1999; English, 1998; Knott, 2010), matematiksel muhakeme becerilerine (Cankoy ve Darbaz, 2010; Çelik, 2010), eleştirel düşünme becerilerine (Nixon-Ponder, 1995), yaratıcılıklarına (Silver, 1997), akademik başarı ve matematiğe yönelik tutumlarına (Silver, 1994; English, 1998) olumlu yönde etki etme potansiyeli vardır. Bu konuda English (1998) problem kurma aktivitelerinin, öğrencilerin matematiksel sembolleri anlama ve onların günlük hayat ile ilişkisini keşfetmelerinde faydalı olacağını belirtmiştir. Kar (2014) problem kurmanın; problem çözme, kavramsal anlama ve yaratıcılıklarının geliştirilmesinde rol oynadığını ifade etmiştir. Aydın (2016) da problem kurmanın problem çözme, analiz, eleştirel düşünme, çıkarım yapma gibi üst düzey becerilerin geliştirilmesinde kullanılan bir araç olduğunu belirtmiştir. Altun (2014b), problem kurmada başarılı olan öğrencilerin matematiğe yönelik korku ve kaygılarının azalacağını, matematiğe karşı olumlu duygular besleyeceklerini belirterek problem kurmanın öğrenciler üzerindeki psikolojik etkilerine vurgu yapmıştır. $\mathrm{Bu}$ nedenlerle problem kurma, öğrencilerin bilgi, beceri ve tutumlarını geliştirmede kullanılan önemli bir öğretim yöntemi olarak düşünülebilir.

Yapılan araştırmalarda problem kurma aktiviteleri farklı şekillerde sınıflandırılmıştır (Christou, Mousoulides, Pittalis, Pitta-Pantazi ve Sriraman, 2005; Silver, 1994; Silver ve Cai, 2005; Stoyanova ve Ellerton, 1996). Bu sınıflamalardan en çok kullanılanı Stoyanova ve Ellerton'ın (1996) serbest, yarı yapılandırılmış ve yapılandırılmış problem kurma sınıflamasıdır. Serbest problem kurmada öğrencilerden konu sinırlandırması olmadan problem kurmaları istenir. Yarı yapılandırılmış problem kurmada ise bir durum, denklem, grafik, şekildeki bilgilerden yararlanılarak problem kurulur. Yapılandırılmış problem kurmada verilen bir problem durumuna ilişkin veriler kullanılır. Bu veriler ya değiştirilir ya da aynen kullanılır (Stoyanova ve Ellerton, 1996). Christou ve diğerleri (2005) öğrencilerin problem kurma aktivitelerini düzenleme, seçme, kavrama ve dönüştürme olmak üzere dört gruba ayırmıştır. Düzenlemede, verilen bilgilerden kısıtlama yapılmadan öğrencilerden problem kurması istenir. Öğrencilerden bir cevap üzerinden problem kurmalarının istendiği aktivite çeşidi seçmedir. Verilen bir denklem ya da eşitlikten yararlanarak problem kurma 
durumları kavrama olarak isimlendirilmiştir. Öğrencilerden bir şekil, grafik ve tabloya uygun problemler kurmaları dönüştürme etkinliklerdir (Christou ve diğ., 2005). Bu iki sınıflama karşılaştırıldığında; serbest problem kurmanın düzenleme ile, yarı yapılandırılmış problem kurmanın dönüştürme ile, yapılandırılmış problem kurmanın ise kavram ile benzerlik gösterdiği söylenebilir. Bu çalışmanın verilerinin toplamasında da yapılandırılmış ve kavrama sınıfındaki problem kurma etkinlikleri kullanılmıştır. Silver (1994), problem kurma etkinliklerinin problem çözümü sürecinde kullanıldığı aşamalara göre üçlü bir sınıflama yapmıştır. Silver (1994) problem kurma etkinliklerinin problem çözüm sürecinin başında, süreç içerisinde ve sürecin sonunda kullanılabileceğini belirtmiştir. Silver ve Cai (2005) öğrencilerin kurdukları problemleri değerlendirirken nicelik, orijinallik ve karmaşıklık kriterlerine göre değerlendirmişlerdir. Bu çalışmada ise öğrencilerin kurdukları problemler çarpma ve bölme işıleminin kavramsal yapılarına uygunlukları bağlamında değerlendirilmiştir.

Çarpma ve bölme işlemleri kavramsal olarak birçok yapıya sahiptir. Toplama ve çıkarma işlemine göre daha çok sayıda kavramsal özelliğinin olduğu söylenebilir. Çarpma ve bölme işlemine yönelik yapılar araştırmacılar tarafından farklı isimlerde ifade edilmiştir (Souviney, 1994; Van de Walle, Karp ve Bay-Williams, 2013). Bu çalışmada Haylock ve Cuckborn'un (2014) belirttiği sınıflama dikkate alınmıştır. Bu sınıflamaya göre çarpma işleminin tekrarlı toplama ve ölçeklendirme yapıları mevcuttur. Tekrarlı toplama yapısının merkezinde "pek çok şeyin pek çok grubu” şeklinde anahtar bir ifade yer almaktadır. Örneğin 9x3 için, değişme özelliği olmakla birlikte, birinci sayı grupların sayısını, ikinci sayı ise nesnelerin sayısını göstermektedir. "Dokuz tane kedim var. Her birini üç yavrusu olduğuna göre toplamda kaç yavru kedi vardır?” şeklinde kurulan bir problem bu yapıya örnek olarak verilebilir. Çarpmanın ölçeklendirme yapısı bazı çalışmalarda karşılaştırma yapısı olarak da isimlendirilmiştir (Holmes, 1995; Kılıç, 2013; Tertemiz, 2017; Van de Walle, Karp ve BayWilliams, 2013). Bu yapı bir çarpanla büyütülmüş bir niceliktir. 9x3 için kurulan "Benim dokuz kalemim var. Arkadaşım ise benim kalem sayımın üç katına sahiptir. Arkadaşımın kaç kalemi vardır?" problemi örnek olarak verilebilir (Haylock ve Cuckborn, 2014). Bölme işleminin aralarında eşit paylaştırma, çarpma işleminin tersi (gruplama), tekrarlı çıkarma işlemi ve oran olmak üzere dört yapısı vardır. Aralarında eşit paylaşım yapısında eşit paylaştırmak anahtar bir ifadedir. 12:3 işlemi için kurulan "12 tane kalem üç öğrenci arasında 
eşit paylaştırılırsa her bir öğrenciye kaç kalem düşer?” problemi bu yapıya örnektir. Bu yapıda 12 nesneden oluşan bir set üç grup halinde düzenlenir, cevap her bir gruptaki nesne sayısıdır. Çarpma işleminin tersi yapısı, verilen bir büyüklük için elde edilebilecek grup sayısını bulmaya yönelik olduğundan "gruplama" olarak isimlendirilebilir. 12:3 işlemi için “12 kalemi arkadaşlarıma üçer üçer paylaştırırsam kaç arkadaşıma kalem vermiş olurum?” bu yapıya uygun bir problemdir. 12 nesne üçlü gruplar halinde düzenlenir, cevap ise grupların sayısıdır. Bölme işleminin çarpma işleminin tersi olma fikri, çarpmanın tekrarlı toplama yapısına benzer olarak bölmenin tekrarlı çıkarma olma fikrini ortaya çıkarır. 12:3 işlemi için “12'den geriye hiçbir şey kalmayacak şekilde kaç defa üç çıkartılabilir?” problemi bu yapı için uygundur. Bölme işleminin oran yapısı da çarpma işleminin ölçeklendirme yapısının tersidir. 12:3 işlemi için "Ben 12 yaşındayım. Kardeşim 3 yaşında. Benim yaşım kardeşimin yaşının kaç katıdır?” problemi bu yapıya uygun kurulan bir problemdir.

Problem kurma konusunda son yıllarda yapılan araştırmalar incelendiğinde, ilkokul (Atalay, 2017; Çarkçı, 2016; Tertemiz, 2017) ve ortaokul öğrencileri (Çetinkaya, 2017; Dinç, 2018; Ekici, 2016; Geçici ve Aydın, 2019; Gizem-Karaaslan, 2018; Güzel, 2017; Işık ve Kar (2015); Kılıç, 2013; Kurt, 2015; Onkun-Özgür, 2018; Say1, 2018; Şahal, 2016; TurhanTürkkan, 2017; Türnüklü, Ergin ve Aydoğdu, 2017, Yalçın, 2017), öğretme adayları (Kanbur, 2017; Yıldız, 2014) ve öğretmenlerin (Çomarlı, 2018; Kılıç ve İncikabı, 2013) problem kurma becerileri üzerine çalışmalar yapıldığı görülmüştür. Ayrıca problem kurma aktivitelerinin ders kitapları ve matematik ders programlarındaki niceliği ve niteliği üzerine çalışmalar da yapılmıştır (Ev Çimen ve Yıldız, 2017; Kalaycı, 2014). Çalışmaların özellikle son yıllarda sıklaştığı ve ortaokul yaş grubundaki öğrenciler üzerine yapılan çalışmaların yoğunlukta olduğu görülmüştür.

$\mathrm{Bu}$ çalışmanın araştırma grubunu oluşturan ortaokul öğrencileri üzerine yapılan çalışmalarda, öğrencilerin problem kurma becerilerinin tespiti (Çetinkaya, 2017; Dinç, 2018; Ekici, 2016), problem kurma becerilerinin diğer beceri ve psikolojik yapılarla ilişkisi (Çelik, 2010; Geçici ve Aydın, 2019) ve problem kurma yaklaşımı kullanılarak yapılan öğretimin sonuçları üzerine (Fidan, 2008; Kurt, 2015; Şahal, 2016) çalışmaların yapıldığı görülmüştür.

Ortaokul öğrencilerin problem kurma becerilerinin genellikle düşük olduğu ve birtakım güçlüklere sahip olduğu da yapılan araştırmalarla ortaya çıkmıştır (Çetinkaya, 2017; Dinç, 2018; Kılıç, 2013; Onkun-Özgür, 2018; Özgen, Aydın, Geçici ve Bayram, 2017; 
Tertemiz, 2017; Türnüklü, Ergin ve Aydoğdu, 2017). Problem kurma becerisinin problem çözme becerisi ile (Akay, 2006; Cankoy ve Darbaz, 2010), akıl yürütme becerisi ile (Çelik, 2010), cebirsel düşünme becerisi ile (Say1, 2018), problem çözmeye yönelik tutum ile (Özgen ve diğ., 2017), okuduğunu anlama ve görsel okuma becerisi ile (Semizoğlu, 2013) ve öz yeterlik inançları ile (Geçici ve Aydın, 2019) ilişkili olduğu da tespit edilmiştir. Ayrıca problem kurma etkinlikleri kullanılarak yapılan öğretimin problem çözme becerisi (Fidan, 2008; Salman, 2012), akademik başarı (Şahal, 2016) ve matematiğe yönelik tutum (Kurt, 2015; Salman, 2012), matematiksel kavramları öğrenme düzeyi ve bilgilerin kalıcılığı (Kurt, 2015) üzerinde olumlu etkilerinin olduğu tespit edilmiştir. $\mathrm{Bu}$ olumlu etkilere karşın uygulanan problem kurma etkinliklerine dayalı öğretimin sonucunda akademik başarı ve matematiğe yönelik tutumda istenen sonuçların alınamadığı sınırlı sayıda çalışmalar da mevcuttur (Güzel, 2017; Şahal, 2016).

Öğrencilerin temel becerileri olan dört işlem becerisi üzerine problem kurma çalışmalarının sınırlı sayıda olduğu ortaya çıkmıştır. Ekici (2016), ortaokul öğrencilerinin dört işleme yönelik problem kurma becerilerini incelediği çalışmasının sonucunda, öğrencilerin problem çözmede olduğu gibi problem kurmada da belirli sıralamalar izlediklerini ve birbirine benzer yollar kullandıklarını belirlemiştir. Kılıç (2013), ilköğretim dördüncü ve beşinci sınıf öğrencilerinin serbest problem kurma aktiviteleri yardımıyla dört işleme yönelik kurdukları problemleri analiz etmiştir. Tertemiz (2017) ilkokul öğrencilerin dört işlem üzerine yapılandırılmış problem kurma becerilerini analiz etmiştir. Çalışmalarda öğrencilerin çarpma ve bölme işleminde toplama ve çıkarma işlemine göre problem kurma konusunda daha başarısız oldukları, birçok güçlük yaşadıkları ortaya çıkmıştır (Kılıç, 2013; Tertemiz, 2017). Bunar (2011) altıncı sınıf öğrencilerinin dört işlem için verilen verileri kullanarak problem kurmada başarılı iken, verilen problemdeki eksik bilgileri tamamlayarak problem kurma ve fazla bilgileri çıkarıp yeniden problem kurmada aynı başarıyı gösteremediklerini tespit etmiştir.

Yukarıdaki çalışmalarda görüldüğ̈ gibi, ortaokul öğrencilerinin çarpma ve bölme işlemine yönelik problem kurmada güçlük yaşandığının tespit edildiği fakat bu işlemlerde yaşanan güçlüklere ilişkin detaylı bir araştırmanın yapılmadığı ortaya çıkmıştır. Bu nedenle, ortaokul öğrencilerinin çarpma ve bölme işlemine yönelik problem kurarken yaşadıkları güçlüklerin açıklanmasına ihtiyaç olduğu söylenebilir. Bu güçlüğün kaynağı üzerine 
yapılacak çalışmalardan elde edilecek sonuçlar, yapılacak öğretimlerin kalitesinin artmasına yardımcı olabilir. Öğrencilerin çarpma ve bölme işlemine yönelik yanlış algılarını ortaya çıkarabilir. Bu sebeplerden dolayı çalışmanın amacı ortaokul öğrencilerinin çarpma ve bölme işleminde problem kurma performanslarını tespit ederek, tespit edilen güçlükleri detaylı olarak açıklamaya çalışmaktır. Bu amaca ulaşabilmek için aşağıdaki araştırma sorularının cevapları aranmıştır.

- Öğrenciler çarpma ve bölme işlemine yönelik ne tür problemler kurmaktadirlar?

- Öğrenciler çarpma ve bölme işlemine ne tür anlamlar yüklemektedirler?

\section{Yöntem}

\section{Araştırmanın Deseni}

Araştırma, nitel araştırma yaklaşımının benimsendiği bir durum çalışması örneğidir. Çünkü durum çalışmalarında, araştırılan bir durum kendi doğal şartlarında zaman ve mekân sınırlılığı dikkate alınarak araştırılır (Kaleli Yılmaz, 2015). Diğer bir ifade ile, durum çalışmalarında sınırlı bir sistemin derinlemesine betimlenmesi ve incelenmesi yapılır (Merriam, 2013).

\section{Araştırma Grubu}

Çalışmanın araştırma grubunu 2017-2018 eğitim öğretim yılında, Türkiye'nin Doğu Anadolu Bölgesi'nde yer alan bir ilinin devlet ortaokulunda öğrenim gören toplam 95 beşinci sınıf öğrencisi oluşturmaktadır. Çalışma, ikinci yazarın ortaokul matematik öğretmeni olarak görev yaptığı devlet ortaokulunda yapılmıştır. Bu nedenle çalışmanın yapıldığı devlet ortaokulu uygun örnekleme yöntemine göre seçilmiştir. Çalışmanın araştırma grubu seçiminde ise ölçüt örnekleme yöntemi kullanılmıştır. Ölçüt örnekleme yönteminin amacı daha önceden belirlenmiş önemli görülen kriterleri sağlayan durumların araştırılmasıdır (Patton, 2014). Bu çalışma için önemli görülen ölçüt, öğrencilerin doğal sayılarda çarpma ve bölme işlemi konusunda temel bilgilere sahip olmalarıdır. Bu nedenle araştırma grubu, "Doğal sayılarda çarpma işlemi”" ve "Doğal sayılarda bölme işlemi” konusunda öğretimleri tamamlanan beşinci sınıf öğrencileri arasından oluşturulmuştur. İlgili konunun öğretiminde kullanılan kaynak kitap incelendiğinde, konunun “çarpma ve bölme işlemlerini yapabilme”, 
"zihinden çarpma ve bölme işlemleri yapma" ve "çarpma ve bölme işlemleri ile ilgili problemleri çözme" içeriklerinden oluştuğu görülmektedir (Cirıtçı, Gönen, Kavas, Özarslan, Pekcan ve Şahin, 2017). Matematik dersi öğretim programında konunun öğretimi için: “En çok üç basamaklı iki doğal sayının çarpma işlemini yapar.”, "En çok dört basamaklı bir doğal sayıyı, en çok iki basamaklı bir doğal sayıya böler.", "Doğal sayılarla çarpma ve bölme işlemlerinin sonuçlarını tahmin eder.", "Doğal sayılarla zihinden çarpma ve bölme işlemlerinde uygun stratejiyi belirler ve kullanır.", "Bölme işlemine ilişkin problem durumlarında kalanı yorumlar.”, "Çarpma ve bölme işlemleri arasındaki ilişkiyi anlayarak işlemlerde verilmeyen ögeleri (çarpan, bölüm veya bölünen) bulur." ve "Dört işlem içeren problemleri çözer.” kazanımları yer almaktadır (MEB, 2017). Araştırma grubunda yer alan beşinci sınıf öğrencilerine ilgili konunun öğretimi, öğretim programı çerçevesinde aynı zamanda araştırma grubunda yer alan öğrencilerin matematik öğretmeni olan ikinci yazar tarafindan tamamlanmıştır.

Görüşme yapılan öğrencilerin seçiminde maksimum çeşitlilik örnekleme yöntemi dikkate alınmıştır. Maksimum çeşitlilik örnekleme yönteminin kullanılmasının sebebi, problem durumunu olabildiğince farklı boyutlardan ele alarak durumlar arasındaki örüntüleri keşfetmektir. Bu örnekleme yöntemindeki amaç da, çeşitlilik gösteren durumlar arasındaki ortak özellikleri bulmaya çalışmak ve bu çeşitlilikten yararlanarak problemin farklı boyutlarını ortaya çıkarmaktır (Yıldırım ve Şimşek, 2011). 95 öğrencinin yazılı olarak kurdukları problemlerin incelenmesi sonucunda farklı yapıda problemler kurdukları tespit edilen öğrencilerle görüşmeler yapılmıştır. Bu bağlamda çarpma işlemi için beş, bölme işlemi için yedi olmak üzere toplam 12 öğrenci ile yarı yapılandırılmış görüşmeler yapılmıştır. Çalışmada öğrencilerin gerçek isimleri yerine Ö1, Ö2, .. , Ö95 şeklinde kodlar kullanılmıştır.

\section{Verilerin Toplanması}

Çalışmanın verileri iki aşamada toplanmıştır. Birinci aşamada çalışmaya katılan tüm öğrencilerden sırasıyla " $12 \times 3$ " ve "12:3" işlemleri için istedikleri sayıda problem kurmaları istenmiştir. Öğrencilerin, öğretmenleri gözetiminde bir ders saati içerisinde kurdukları problemler yazılı olarak toplanmıştır. Çalışmanın ikinci aşamasında farklı özelliklerde problemler kuran 12 öğrenci ile yarı yapılandırılmış görüşmeler yapılmıştır. Görüşmeler her 
bir öğrenci ile bireysel olarak gerçekleşmiştir. Görüşmeler ilk uygulamadan bir hafta sonra gerçekleştirilmeye başlanmış ve bir hafta içerisinde tamamlanmıştır. Görüşmelerde daha önceden hazırlanan görüşme formu yardımıyla, öğrencilerle birlikte öğrencilerin kurdukları problemler gözden geçirilmiş olup çarpma ve bölme işlemlerinin onlar için ne anlam ifade ettiği sorgulanmıştır. Bu amaçla öğrencilere sırasıyla "Yazdı̆̆ın problemi açıklar mısın?" ve “Çarpma/bölme işlemi denince aklına ne geliyor?” soruları sorulmuştur. Görüşmeler öğrencilerin boş saatlerinde, öğretmenleri olan ikinci yazar ile rahatsız edilmeden görüşebilecekleri bir odada gerçekleşmiştir. Görüşmeler her bir öğrenci için ortalama 10 dakika sürmüştür. Görüşmeler ses kayıt cihazı yardımıyla kayıt altına alınmıştır.

\section{Veri Analizi}

Öğrencilerle yapılan görüşmeler yazılı metine dönüştürülmüş ve veri analizine hazır hale getirilmiştir. Çalışmadan elde edilen veriler içerik analizi yardımıyla çözümlenmiştir. İçerik analizi, toplanan verilerin derinlemesine analizini gerektiren önceden belirlenmeyen temaların ve boyutların ortaya çıkarılmasını sağlayan bir nitel veri analizi yöntemidir (Yıldırım ve Şimşek, 2011). Bu çalışmada önceden belirlenen tema ya da kategoriler belirlenmediği için bu yöntem kullanılmıştır. Çalışmada ortaya çıkan kategorilerin elde edilmesinde araştırmacılar ortak olarak değerlendirme yapmışlardır. Kategorilerin verilerle uyumu konusunda araştırmacılar aralarında uzlaşma sağlamışlardır. Veri analizinin güvenirliği için harici bir uzmandan yardım alınmıştır. Söz konusu uzman, bir devlet ortaokulunda görev yapan, ilköğretim matematik eğitimi anabilim dalında doktora tezine sahip bir matematik öğretmenidir. Kategoriler ve kategorilerin oluşmasını sağlayan öğrenci ifadeleri uzmana sunulmuş, verilerle kategorilerin uyumlu olup olmadığı konusunda görüşü alınmıştır. Uzman, çalışmadan elde edilen verilerin kategorilerle büyük oranda uyumlu olduğunu teyit etmiştir. Kategorilere yönelik güvenirlik Miles ve Huberman (1994) tarafından geliştirilen güvenirlik hesaplama formülü yardımıyla hesaplanmıştır. Bu formülde görüş birliğine varılan kategorilerin sayısı, görüş ayrılığına varılan kategorilerin toplam sayılarına bölünerek elde edilen sonucun 100 ile çarpılmasıyla uyuşum yüzdesi belirlenir. Öğrencilerin çarpma işlemi için kurdukları problemlere yönelik kategorilerde uyuşum yüzdesi .87 iken bölme işlemi için kurdukları problemlere yönelik kategorilerde uyuşum yüzdesi .84 olarak hesaplanmıştır. Kodlayıcılar arasındaki uyuşum yüzdesi .70'den büyük 
olduğu için içerik analizindeki güvenirliğin yeterli olduğu kanısına varılmıştır. Uzlaşı sağlanamayan durumlar için araştırmacılar ve uzman bir araya gelerek görüş birliğine varmışlardır. Örneğin, daha önce bölme işlemi için oluşturulan eksik ve fazla paylaştırma kategorileri uzmanın önerisi ile yanlış paylaştırma kategorisi altında birleştirilmiştir.

\section{Bulgular}

$\mathrm{Bu}$ bölümde sırasıyla öğrencilerin işlemlere yönelik kurdukları problemlerin yapısal analizine ve öğrencilerle yapılan görüşmelerden elde edilen bilgilere yer verilmiştir. Çarpma ve bölme işlemi ile ilgili elde edilen sonuçlar bölümler halinde sunulmuştur.

Öğrencilerin çarpma işlemine yönelik kurdukları problemler ve yükledikleri anlamlar

Öğrencilerden yazılı olarak "12x3" işlemi için istedikleri sayıda problem kurmaları istenmiştir. Öğrenciler birer tane problem kurmayı tercih etmişlerdir. Öğrencilerin üçü herhangi bir problem kurmamıştır. Öğrencilerin kurdukları problemlerin matematiksel uygunluk bakımından iki kategoriye ayrıldığı tespit edilmiştir. Öğrencilerin matematiksel olarak uygun olan problemlerinin ölçeklendirme ve tekrarlı toplama yapısına uygun oldukları belirlenmiştir. Matematiksel olarak uygun olmayan problemlerin ise beş alt kategori altında toplandığ1 ortaya çıkmıştır. Bu alt kategoriler; gerçek hayat problemi olmayan alıştırma, toplama işlemine yönelik problemler, çıkarma işlemine yönelik problemler, bölme işlemine yönelik paylaştırma problemleri ve istenen problemin verileri ile ilişkili olmayan ilişkisiz alt kategorileridir. Şekil 1'de öğrencilerin kurdukları problemlerin özelliklerine göre sınıflandırılması sunulmuştur. 
Şekil 1. Öğrencilerin Kurdukları Çarpma Problemlerinin Özellikleri

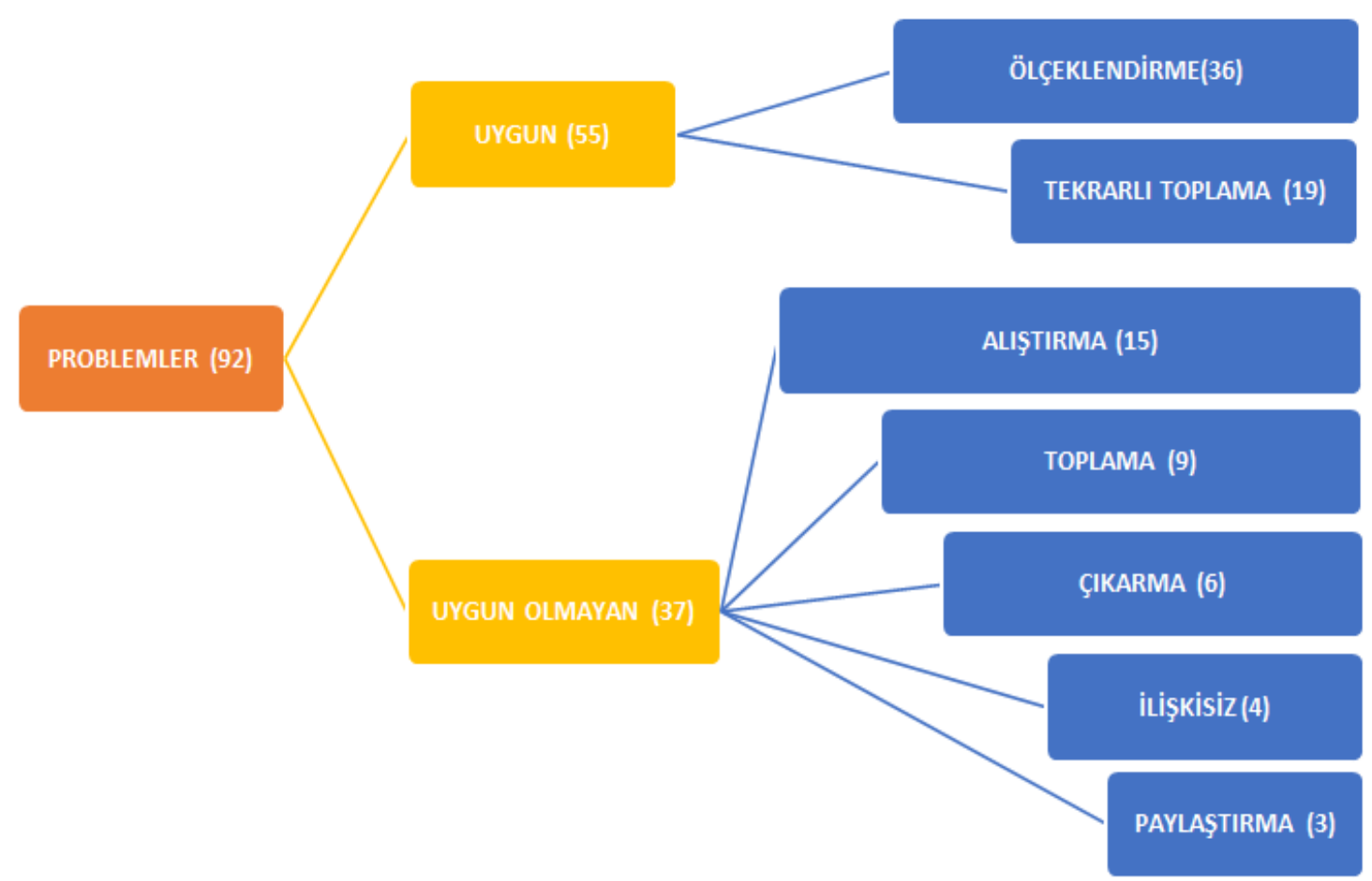

Şekil 1 incelendiğinde 55 öğrencinin uygun problemler kurabildikleri, 37 öğrencinin ise çarpma işlemine uygun problem kuramadıkları ortaya çıkmıştır. Üç öğrenci herhangi bir problem kuramamıştır. Buna göre öğrencilerin çoğunun çarpma işlemine yönelik uygun problem kurabildikleri söylenebilir. Buna rağmen öğrencilerin azımsanmayacak bir kısmının da çarpma işlemine uygun bir problem kuramadıkları, dolayısıyla çarpma işlemine yönelik problem kurmada güçlük yaşadıkları söylenebilir. Öğrenciler tarafından üretilen 55 problemin çarpma işleminin ölçeklendirme (36) ve tekrarlı toplama (19) yapısına uygun, doğru problemler kurdukları ortaya çıkmıştır. Buna göre öğrenciler çarpma işleminin en çok ölçeklendirme yapısını göz önünde bulundurdukları söylenebilir. Aşağıda çarpma işlemine uygun olarak değerlendiren ölçeklendirme ve tekrarlı toplama yapılarına uygun problem örnekleri sunulmuştur.

Ö11: Ela'nın 12 kitabı var. Arkadaşının kitabı Ela'nınkinin 3 katıdır. Buna göre arkadaşının kaç tane kitabı var? 
Ö39: Bir mağazada tanesi 12TL olan pantolondan 3 tane aldım. Buna göre kaç TL ödemem lazım?

37 öğrenci çarpma işleminin özelliklerine uygun bir problem kuramamışlardır. 15 öğrenci problem için sadece “ $12 \times 3$ işleminin sonucu nedir?” şeklinde problem unsuru taşımayan alıştırma şeklinde sorular yazmıştır. Dokuz öğrenci toplama, altı öğrenci çıkarma, üç öğrenci paylaştırma kavramlarına yönelik problemler kurmuşlardır. Dört öğrenci ise kurulması istenen problemin verilerine uygun olmayan ilişkisiz problem kurmaya çalışmıştır. Aşağıda çarpma işlemine uygun problem kuramayan öğrencilerin kurdukları problemlerin özelliklerini yansıtan; alıştırma, toplama, çıkarma, ilişkisiz ve paylaştırma kategorilerine uygun örnekler sırasıyla sunulmuştur.

Ö8: $12 \times 3$ 'ün çarpımı kaçtır?

Ö2: 12 çocuk aralarında saklambaç oynuyorlar. 3 çocuk daha onlara katıldı. Şimdi kaç çocuk saklambaç oynuyor?

Ö35: Caner'in babası Caner'e 12TL vermiş. 3 TL'sini harcamış. Buna göre kaç TL'si kalmış?

Ö24: Benim 18 tane kalemim vardır. 10 tanesini kardeşime verdim. Kaç kalemim kaldı?

Ö1: Biz 4 arkadaşız. Annem 12 tane börek getirdi. Bunları nasıl paylaştıracağız?

Kurdukları problemlere bakılarak farklı çarpma yapılarında olduğu düşünülen beş öğrenci ile yapılan görüşmelerde “Çarpma işlemi denince aklınıza ne geliyor?" sorusu sorulmuştur. Elde edilen yanıtların dört kategoriye ayrıldığı ortaya çıkmıştır. Bu soruya öğrencilerden ikisi tekrarlı toplama, birer öğrenci de çarpım tablosu, artma ve yorum kategorilerinde görüş bildirmişlerdir. İki öğrenci çarpmanın "Çarpma tekrarlı toplamadır. Uzun uzun toplama işlemi yaparsak işimiz daha zor olur. Çarpma işlemi bu işlemleri daha kolay yapmamızı sağlar” ve "Bir sayının birkaç kez toplanmasıdır" diyerek tekrarlı toplama yapısına vurgu yapmışlardır. Bir öğrenci çarpma işleminin "Çarpım tablosu” olduğunu söyleyerek gerçek hayattan kopuk bir açıklama yapmıştır. Bir öğrenci de çarpma işlemini "Bir sayıyı çoğaltan ve bir sayı az iken onu artıran” olarak ifade etmiştir. Bir öğrenci de 
“Güzel bir şey. Dört işlemden en güzeli, gerçekten çok kolay” şeklinde açıklama yaparak çarpma işlemi hakkındaki duygularını belirtmiştir. Görüşülen öğrencilerden sadece ikisinin çarpma işleminin yapılarına uygun görüşte oldukları ortaya çıkmıştır. Buna göre görüşülen öğrencilerin çoğunun çarpma işlemine, çarpma işleminin kavramsal anlamıyla ters düşebilecek anlamlar yükledikleri söylenebilir.

Öğrencilerin bölme işlemine yönelik kurdukları problemler ve yükledikleri anlamlar

Bu bölümde, öğrencilerden “12:3” işlemine yönelik problem kurmaları istenmiştir. Öğrencilerin kurdukları problemlerin öncelikle matematiksel uygunluk bağlamında iki kategoriye ayrıldığı tespit edilmiştir. Matematiksel olarak uygun kurulan problemlerin üç alt kategoride toplandığı ortaya çıkmıştır. Matematiksel olarak belirtilen işleme uygun olmayan problemlerin yedi alt kategoriye ayrıldığı belirlenmiştir. Şekil 2'de öğrencilerin kurdukları problemin özellikleri sunulmuştur.

Şekil 2. Öğrencilerin Kurdukları Bölme Problemlerinin Özellikleri

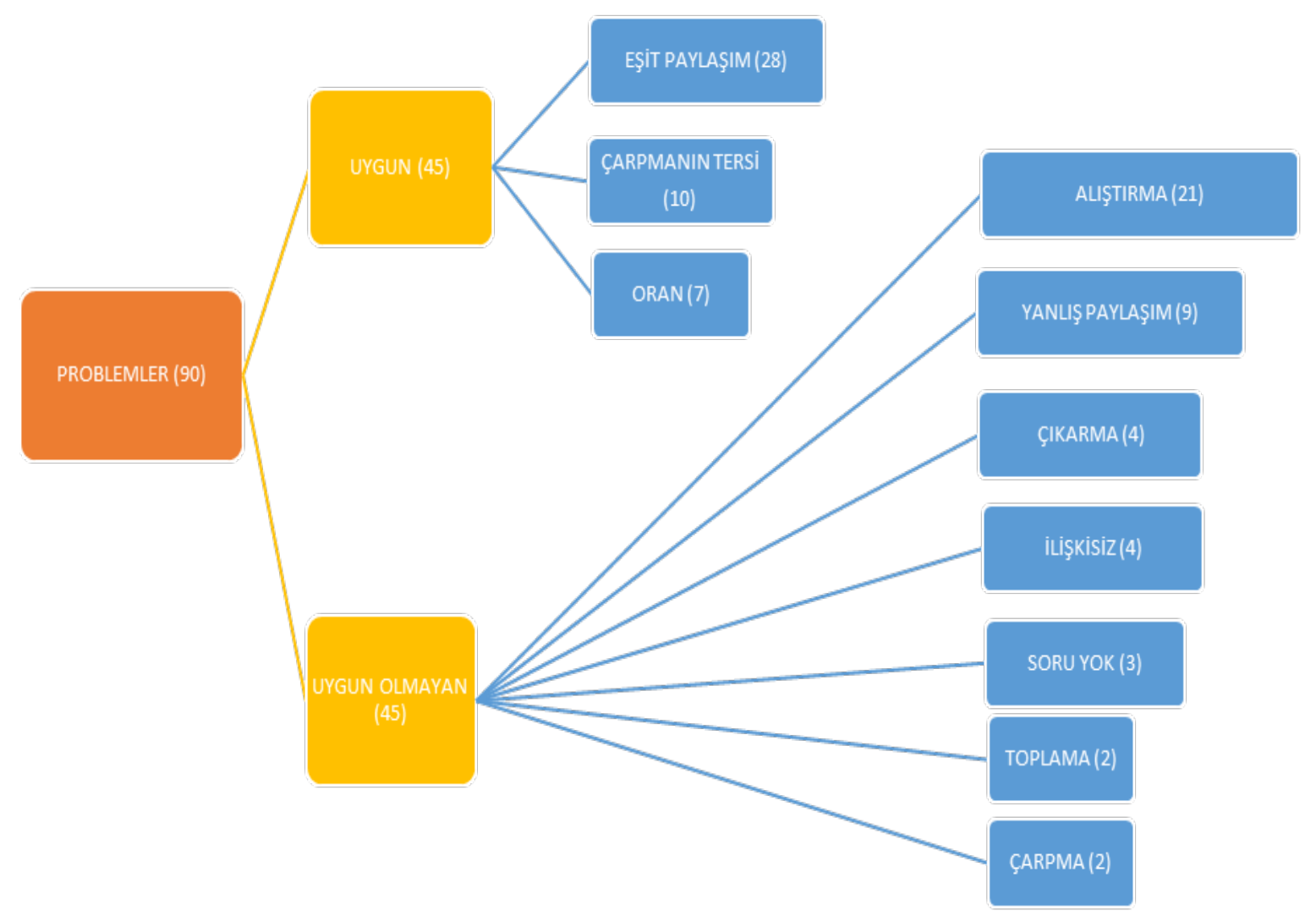


Şekil 2 incelendiğinde, öğrencilerin beşinin hiçbir problem kuramadığı, kurulan problemlerin yarısının ise matematiksel olarak uygun problem özelliği taşımadıkları ortaya çıkmıştır. Buna göre öğrencilerin bölme işlemine yönelik problem kurma konusunda güçlük yaşadıkları söylenebilir. Matematiksel olarak uygun kurulan problemlerde eşit paylaşım yapısının ağırlıkta olduğu görülmüştür. Bu yapıları çarpmanın tersi ve oran yapısı izlemiştir. Öğrencilerden hiçbiri tekrarlı çıkarma yapısına uygun problem kurmamıştır. Aşağıda bölme işleminin yapılarına uygun problem kuran öğrencilerden örnekler sunulmuştur.

Ö85: Bir baba çarşıdan 12 tane şeker getirdi. Baba 3 kardeşe şekerleri eşit paylaştırınca her kardeşe kaç tane şeker düşer?

Ö88: Bende 12 lira var. Arkadaşlarıma üçer üçer dağıttım. Kaç arkadaşıma dağıtırım?

Ö60: Ali'nin 12 kalemi var. Ali'nin arkadaşı Elif'in onun 1/3'ü kadardır. Elif'in kaç kalemi vardır?

Matematiksel olarak uygun olmadıkları değerlendirilen problemlerin başında alıştırma özelliğindeki problemler vardır. Bu problemlerde sadece işlem sonucu sorulmakta, problem özelliği taşımamakta ya da gerçek hayatla ilişki kurulamamaktadır. 10 öğrenci problemlerinde "aralarında eşit paylaşım” kavramını yanlış uygulamışlardır. Kimi öğrenciler problemlerinde belirttikleri 12 adet nesneyi iki ya da dört kişiyle paylaşarak eksik ya da fazla kişiyle paylaşım yapmışlardır. Bazı öğrencilerin problemleri çarpma, toplama ve çıkarma işlemine yönelik hazırlanmıştır. Dört öğrencinin problemi verilerle ilişkili olmayıp üç öğrenci de problemlerinde soru ifadesine yer vermemiştir. Aşağıda öğrencilerin alıştırma, yanlış paylaşım, çıkarma, ilişkisiz, soru yok, toplama ve çarpma kategorilerinde değerlendirilen örnek problemleri sırasıyla sunulmuştur.

\section{Ö18: 12:3 bölme işlemini yap.}

Ö50: Benim 12 kalemim var. Kardeşimin 3 kalemi var. Biz bunları eşit bir şekilde paylaşacă̆ız. Her birimize kaç kalem düşer?

Ö67: Benim 12 liram var. 3 arkadaşımla paylaştım. Her birimize kaç lira düşer? 
Ö24: Benim 12 tane çikolatam var. Bunların üçünü arkadaşıma verdim. Buna göre benim kaç çikolatam kaldı?

Ö22: Babam bize $1 \mathrm{~kg}$ kestane ald. Her birimize 3 tane yetse kaç kişi kestane yemiş olur?

Ö59: Doğum günüm için 12 dilimlik pastayı 3 'e bölüp arkadaşımla yedim.

Ö35: Erdem 12 yaşında kardeşi ise 3 yaşında. Her ikisinin yaşları toplamı nedir?

Ö26: Tanesi 12TL olan silgilerden 3 tane almak istiyorum. Silgileri almak için kaç TL'ye ihtiyacim var?

Kurdukları problemlere bakılarak farklı bölme yapılarında olduğu düşünülen yedi öğrenciye bölme işleminden ne anladıklarını ifade etmeleri istenmiştir. Öğrencilerin ifadeleri tekrarlı çıkarma, bölünme, işlem, küçültme ve yorum kategorilerinde toplanmıştır. İki öğrenci tekrarlı çıkarma vurgusu yaparak bölme için "Tekrarlı çıkarma işlemidir” ve "Bölenin, bölünenden birkaç kez çıkartılmasıdır" açıklamalarını yapmışlardır. İki öğrenci bölünme vurgusu yaparak "İki sayının birbiri ile bölünmesidir. Sadece bölünen ve bölen sayılar bölünür” ve “Bir sayının başka sayıya bölünmesidir” ş̧eklinde bir açıklama yapmışlardır. Bir öğrenci bölme işleminin algoritmasını açıklamaya çalışarak "12:3 için, ben ilk önce 12 de kaç üç var diye bakarım. Sonra cevabı üçün altına yazarım. Sonra cevabı bulurum” şeklinde işlemsel bir açıklama yapmıştır. Bir öğrenci de “Büyük sayıları küçültür” diyerek küçültme, azaltma vurgusu yapmıştır. Son olarak bir öğrenci bölme işlemine yönelik duygularını dile getirerek "Güzel o da gerçek gibi (gerçek hayatla bağlantı anlamında). Sallamadığım sürece çok güzel" yorumunu yapmıştır. Buna göre öğrencilerin bölme işlemine yönelik uygun anlayış geliştirme konusunda güçlük yaşadıkları söylenebilir.

\section{Sonuç, Tartışma ve Öneriler}

$\mathrm{Bu}$ çalışma, öğrencilerin çarpma ve bölme işlemine yönelik problem kurma becerileri ile bu işlemlere yönelik yükledikleri anlamların ortaya çıkarılması amacıyla yapılmıştır. Çalışmada ilk olarak öğrencilerin çarpma işlemine yönelik performansları değerlendirilmiştir. Çoğu öğrencinin verilen çarpma işlemine ait uygun problemler kurdukları görülmüştür. Bölme işlemine yönelik yapılan çalışmalar sonucunda, öğrencilerin yarısı matematiksel 
olarak uygun problemler kurabilirken diğer yarısının ise bu konuda başarısız oldukları ortaya çıkmıştır. Çalışmada elde edilen bu sonuçlar Kılıç'ın (2013) çalışmasındaki sonuçlarla örtüşmektedir. Kılıç (2013), çalışmasındaki beşinci sınıf öğrencilerinin yaklaşık yarısının çarpma ve bölme işlemine yönelik problem kurma etkinliğinde güçlük yaşadıklarını tespit etmiştir. Silver ve Cai (1996), 509 ortaokul öğrencisine dört işlem gerektiren problem durumları vermiş ve bu durumlardan hareketle hikâye oluşturarak problem kurmalarını istemiştir. Çalışmanın sonucunda öğrencilerin çoğunun kitap benzeri problem kurdukları ve en az bir tane çözülebilir problem kurdukları tespit edilmiştir.

Çarpma ve bölme işlemindeki öğrenci performansları birbiri ile karşılaştırıldığında, öğrencilerin bölme işleminde daha başarısız oldukları belirlenmiştir. Çalışmadan elde edilen bu sonuç Kılıç (2013) tarafından yapılan çalışma sonuçları ile çelişmekte, Tertemiz (2017) tarafından yapılan çalışma sonuçları ile örtüşmektedir. Kılıç (2013), çalışmasındaki öğrencilerin bölme işleminde daha yüksek oranda başarılı olduğunu belirtirken Tertemiz (2017) çalışmasındaki dördüncü sınıf öğrencilerinin çoğunun çarpma ve bölme işlemine uygun problemler kurduklarını belirterek başarı oranının çarpma işleminde daha yüksek olduğunu tespit etmiştir. Öğrencilerin çarpma işlemine göre bölme işleminde problem kurmada daha başarısız olmalarının sebebi: bölme işleminin çarpma işlemine göre daha fazla işlem yapısına sahip olması, bölme işleminin kavramsal olarak anlaşılmasında çarpma işlemine yönelik kavramsal anlayışı da içermesi olabilir. Bu nedenle öğrencilerin çarpma işleminde sahip oldukları güçlüklerin bölme işlemine yansıdı̆̆ı, bölme işleminin çarpma işleminden bağımsız kendine özgü özellikleri ile birleşmesi ile yaşanılan güçlüklerin bölme işleminde daha yoğun görülmesi olağan bir sonuç olarak değerlendirilebilir. Öğrencilerin problem kurma becerilerini geliştirebilmek için matematik dersinin öğretimi sürecinde problem kurma aktivitelerine yer verilmesi önerilebilir. Ayrıca öğrenciler tarafından kurulan problemlerin akranları tarafından sınıf ortamında değerlendirme çalışmalarının yapııması, öğrencilerin ilgili kavramlara yönelik anlayışlarının geliştirilmesinin yanında sahip oldukları kavram yanılgılarının tespiti ve giderilmesi adına da faydalı olacaktır. Çünkü problem kurma öğrencilerin anlayışlarının ve başarılarının tespitinde kullanılabilen önemli bir araçtır (Kinach, 2002; Lin, 2004; Silver ve Cai, 2005; Stoyanova, 1998). Buna rağmen daha önce yapılan araştırmalarda matematik öğretmenlerinin zaman yetersizliğinden dolayı derslerinde problemler kurma etkinliklerine yer veremedikleri ortaya çıkmıştır (Kalaycı, 2014). 
Matematik dersinin öğretimi için kullanılan kitaplardaki problem kurma etkinliklerinin nicelik ve nitelik olarak yetersiz oldukları tespit edilmiştir (Ev Çimen ve Yıldız, 2017; Kalaycı, 2014). Bu nedenle matematik derslerinin öğretimi için hazırlanan programlar ve kullanılan kaynaklarda problem kurma etkinliklerinin sayısının arttırılması önerilebilir.

Bunar (2011), altıncı sınıf öğrencilerinin verilen verileri kullanarak problem kurma etkinliklerinde başarılı iken verilen problemdeki fazla ve eksik veriler üzerinde değişiklik yapılarak problem kurmada aynı başarıyı göstermediklerini tespit etmiştir. Bu çalışmada da verilen bir işlem ile ilgili problem kurma etkinliklerinde öğrencilerin daha fazla güçlük yaşadıkları ortaya çıkmıştır. Buna göre problem kurma etkinliklerinde serbest problem kurma aktivitelerinden yapılandırılmış aktivitelere doğru gidildikçe öğrencilerin yaşadıkları güçlüklerin arttığı söylenebilir. Ngah, İsmail, Tasir ve Said (2016) de yaptıkları çalışmada öğrencilerin serbest, yarı yapılandırılmış ve yapılandırılmış problem kurma becerilerini incelemiştir. Çalışmalarının sonucunda öğrencilerin yarı yapılandırılmış ve yapılandırılmış problem kurma aktivitelerinde daha başarısız olduklarını tespit etmişlerdir. Benzer şekilde, Kojima ve Miwa (2008) öğrencilerin verilen probleme benzer problem kurmada güçlük yaşamazken bir durumu ya da çözümü değiştirilen problemi kurmada güçlük yaşadıklarını belirtmiştir. Öğrencilerin serbest problem kurma aktivitelerinde daha başarılı olmaları: öğrencilerin bu aktivitelerde kuracakları doğru problem seçeneklerinin oldukça fazla olmasından kaynaklanıyor olabilir. Yapılandırılmış problem kurma aktivitelerinde sınırları belirlenmiş bir özel işlem için problem kurulması istenir. $\mathrm{Bu}$ problem kurma becerisi öğrencilerin işlemlere yönelik doğru bir anlayışta olmasını gerektirecektir. Öğrencilerin çarpma ve bölme işlemine yönelik doğru bir anlayış geliştirmesinde yaşanılan güçlükler dikkate alındığında, öğrencilerin yapılandırılmış problem kurma aktivitelerinde daha başarısız olmaları olağan bir durum olarak değerlendirilebilir. Bu bağlamda, ilgili konuların öğretimi sırasında öğrencilerin bütün problem kurma aktiviteleri ile karşılaşmaları sağlanabilir. Özellikle öğrencilerin yapılandırılmış problem kurma aktivitelerinde zorlandıkları göz önünde bulundurularak ilgili aktivitelerin üzerinde durulabilir.

Öğrencilerin çarpma işleminin sırasıyla en çok ölçeklendirme ve tekrarlı toplama yapısına uygun problemler kurdukları ortaya çıkmıştır. Öğrenciler bölme işleminde en çok eşit paylaştırma yapısını uygun problemler kurmuşlardır. Bölme işleminin tekrarlı çıkarma 
yapısına uygun çok az sayıda problem oluşturulmuştur. Kılıç (2013) çalışmasında, öğrencilerin çarpma işleminin sırasıyla en çok tekrarlı toplama ve ölçeklendirme yapısına, bölmenin ise eşit paylaşım yapısına uygun problem kurduklarını tespit etmiştir. Bu çalışmada farklı olarak, çarpma işleminin en çok ölçeklendirme yapısına uygun problemler kurulmuştur. Tertemiz (2017) tarafından yapılan çalışmadaki öğrenciler ise çarpma ve bölme işleminin en çok eşit gruplara ayırma yapısını vurgulamışlardır. Öğrencilerin işlemlerin bazı yapılarına göre daha çok problem kurmaları, öğrencilerin bu yapıları daha çok benimsedikleri anlamına gelebilir. $\mathrm{Bu}$ durumun sebebi: ilgili konunun öğretimi sırasında bazı yapılara yoğunluk verilmesi olabilir. Bu sorunların üstesinden gelebilmek için ders öğretiminde işlemlerin tüm yapılarına eşit vurgu yapılmalı, sadece bir yapıya odaklanılmamalıdır. Aksi takdirde ilerideki öğrenme süreçlerinde güçlükler yaşanabilmektedir (Haylock ve Cuckborn, 2013). Ders programlarının ve kaynak kitaplarının da tüm yapılara eşit vurgu yapacak şekilde düzenlenmesi faydalı olacaktır.

Öğrenciler tarafından kurulan fakat verilen çarpma ve bölme işlemlerine uygun olmayan problemleri değerlendirildiğinde, en çok alıştırma özelliğinde, gerçek hayat problemi olmayan problemlerin üretildiği ortaya çıkmıştır. Ayrıca öğrenciler başka işlemlere yönelik problem kurmalarının yanı sıra, soru cümlesi olmayan ve verilen işlemlerle ilişkisiz olan problemler kurdukları tespit edilmiştir. Bazı öğrenciler eşit paylaşım kavramını problemlerine yansıtamamışlardır. Eşit paylaşım yerine eksik, fazla ya da eşit olmayan paylaşımın olduğu problemler kurmuşlardır. Çalışmadan elde edilen bu sonuç, ortaokul öğrencilerinin problem kurma konusunda birtakım güçlüklere sahip olduklarının tespit edildiği araştırma sonuçları ile örtüşmektedir (Çetinkaya, 2017; Dinç, 2018; Onkun-Özgür, 2018; Tertemiz, 2017; Türnüklü, Ergin ve Aydoğdu, 2017). Öğrencilerin kurdukları problemlerde alıştırma özelliğindeki problemlerin fazlalığı, bazı öğrencilerin çarpma ve bölme işlemini gerçek hayatla ilişkilendirme konusunda güçlük yaşadıkları anlamına gelebilir. Bu durumun sebebi ders öğretimi sırasında kullanılan soruların niteliği olabilir. Dersin öğretimi sırasında gerçek hayat örneklerine daha çok yer verilebilir. Örneğin, sınıflarda market ortamı oluşturularak öğrencilere çarpma ve bölme işlemi gerektiren alışveriş oyunları oynatılabilir. Bu kapsamda drama temelli uygulamaların yapılması önerilebilir. 
Kılıç (2013) yaptı̆̆ çalışmada, öğrencilerin diğer işlemlere yönelik problem kurma, eksik veri kullanma, doğal sayı yerine ondalık sayı kullanma, alıştırma yazma ve farklı problemlere yönelik problem kurma güçlükleri yaşadıklarını tespit etmiştir. Bu çalışmada olduğu gibi, öğrencilerin en çok alıştırma sorusu yazdıklarını belirtmiştir. Tertemiz (2017), öğrencilerin kurdukları problemleri: sözel hikâye problemi, sözel alıştırma problemi, doğru problemler (problemin kuruluşunu değiştirme), ilgisiz problem kurma, eksik veri kullanma ve ifadenin anlaşılamadığı durumlar kategorileri altında değerlendirmiştir. Çalışmada elde edilen kategoriler yukarıda belirtilen çalışmalarla çoğunlukla benzerlik göstermekle birlikte bölme işlemi için tespit edilen yanlış paylaşım kategorisi ilk defa tespit edilen bir güçlük olmuştur. Öğrenciler tarafından bölme işleminin eşit paylaştırma yapısının anlaşılmasında güçlük yaşanmasının sebebi, sınıf ortamında kullanılan dil olabilir. Bölme işlemi için sadece paylaşma ve bölme ifadeleri kullanmak, bu paylaşım ve bölünmenin eşit olması gerektiğini arka plana itmiş olabilir. Bu tür güçlüklere sebebiyet vermemek için öğretmenlerin bölme işlemi için kullandıkları ifadelerde dikkatli olması, paylaşımın eşit olması gerektiğinin vurgulanması yerinde olacaktır.

Öğrencilerle yapılan görüşmelerde, öğrencilerin çarpma ve bölme işlemine yönelik yükledikleri anlamlar anlaşılmaya çalışılmıştır. Öğrenciler çarpma işlemine tekrarlı toplama anlamının yanında çarpım tablosu ve artma anlamlarını yüklemiş̧lerdir. Bir öğrenci de çarpma işlemi ile ilgili duygularını ifade etmiştir. Öğrenciler bölme işlemi için tekrarlı çıkarmanın yanı sıra bölünme, işlemsel algoritma ve küçültme anlamlarını yüklemişlerdir. Bir öğrenci de bölme işlemi ile ilgili duygularını belirtmeyi tercih etmiştir. Görüşülen öğrencilerin çoğunun çarpma ve bölme işlemine yönelik kavramsal anlayışa uygun olmayan, gerçek hayattan kopuk, işlemsel özelliklere odaklanan bir anlayışta olduğunu söylemek mümkündür. Öğrencilerin çarpma ve bölme işlemine yönelik sahip oldukları gerçek hayattan kopuk anlayışların öğrencilerin problem kurma aktivitelerinde güçlük olarak yansıdı̆̆ı düşünülmüşsür. Öğrencilerin çalışmada en sık karşılaşılan güçlüğü olan alıştırma yazma güçlüğünün kaynağı da öğrencilerin işlemleri gerçek hayat ile ilişkilendirememeleridir. Çalışmadan elde edilen bu sonuç Schoenfeld'in (1991) eleştirilerini akıllara getirmiştir. Schoenfeld (1991) okullarda öğrencilerin problem çözerken gerçekçi düşünmelerini göz ardı ettiklerini ve matematiği gerçek hayatla ilişkilendirmediklerini belirtmiştir. Matematik eğitiminin amaçlarından biri matematiği günlük hayatta ve diğer alanlarda kullanabilmektir 
(Dinç, 2018). Ma (2010), matematik öğretiminin okul dışındaki yaşam ile ilişskilendirilmesinin öğrencilerin matematiği anlamalarında kolaylık sağlayabileceğini belirtmiştir. Abu-Elwan (2002) ve English (1998) problem kurmanın öğrencilerin matematiği gerçek hayat ile ilişkilendirmesine katkı sağlayabileceğini vurgulamışlardır. Knott (2010) sınıf ortamında kullanılan problem kurma aktivitelerinin öğrencilerin matematiği anlamalarına katkıda bulunduğunu ifade etmiştir. Buna göre öğrencilerin çarpma ve bölme işlemlerine yönelik doğru bir anlayışa sahip olmalarının, işlemleri gerçek hayat ile ilişskilendirmeleri ile mümkün olabileceği söylenebilir. Bu ilişkinin kurulması, dolayısıyla öğrencilerin işlemlere yönelik doğru anlayış sahibi olmalarında problem kurmanın önemli bir araç olduğu söylenebilir. Bu nedenle öğrencilerin işlemlere yönelik doğru anlayışta olmaları için de problem kurma aktivitelerinin kullanılması önerilebilir.

\section{Makalenin Bilimdeki Konumu (Yeri)}

\section{Matematik ve Fen Bilimleri Eğitimi Bölümü/Matematik Eğitimi}

\section{Makalenin Bilimdeki Özgünlüğü}

Yapılan literatür incelemesi sonucunda, ortaokul öğrencilerinin çarpma ve bölme işlemine yönelik problem kurmada güçlük yaşandığının tespit edildiği fakat bu işlemlerde yaşanan güçlüklere ilişkin detaylı bir araştırmanın yapılmadığı ortaya çıkmıştır. Bu nedenle, ortaokul öğrencilerinin çarpma ve bölme işlemine yönelik problem kurarken yaşadıkları güçlüklerin açıklanmasına ihtiyaç olduğu söylenebilir. Bu güçlüğün kaynağı üzerine yapılacak çalışmalardan elde edilecek sonuçlar, yapılacak öğretimlerin kalitesinin artmasına yardımcı olabilir. Öğrencilerin çarpma ve bölme işlemine yönelik yanlış algılarını ortaya çıkarabilir. $\mathrm{Bu}$ çalışmanın amacı da ortaokul öğrencilerinin çarpma ve bölme işleminde problem kurma performanslarını tespit ederek, tespit edilen güçlükleri detaylı olarak açıklamaya çalışmaktır. 


\section{Kaynakça}

Abu-Elwan, R. (2002). Effectiveness of problem posing strategies on prospective mathematics teachers' problem solving performance. Journal of Science and Mathematics Education in S.E. Asia, 25(1), 56-69.

Akay, H. (2006). Problem kurma yaklaşımı ile yapılan matematik öğretiminin ögrencilerin akademik başarısı, problem çözme becerisi ve yaratıcıllğ incelenmesi. (Yayınlanmamış doktora tezi). Gazi Üniversitesi, Ankara.

Akay, H., Soybaş D., \& Argün Z. (2006). Problem kurma deneyimleri ve matematik öğretiminde açık-uçlu soruların kullanımı. Kastamonu Eğitim Dergisi, 14(1), 129-146.

Altun, M. (2014a), Matematik Öğretimi 5-6-7-8. Sinıflar (10.baskı). Bursa: Aktüel Yayınları.

Altun, M. (2014b). Eğitim fakülteleri ve matematik öğretmenleri için liselerde matematik ögretimi. (5. Bask1). Bursa: Aktüel Alfa Akademi.

Atalay, Ö. (2017). İlkokul 4. sını öğrencilerinin kesirler konusunda bilgisayar animasyonları yardımıyla problem kurma becerilerinin incelenmesi (Yayınlanmamış yüksek lisans tezi). Recep Tayyip Erdoğan Üniversitesi, Rize.

Aydın, Ş. (2016). Ortaokul 8. sınıf ögrencilerin matematik dersine ve problem kavramına yönelik görüşleri. (Yayımlanmamış doktora tezi). Gazi Üniversitesi Eğitim Bilimleri Enstitüsü, Ankara.

Baki, A. (2014). Kuramdan uygulamaya matematik ĕğitimi. (5. Baskı). Ankara: Harf Eğitim Yayıncılik.

Baykul, Y. (2014). Ortaokullarda matematik öğretimi. (2 baskı). Ankara: Pegem Akademi.

Bonotto, C., \& Dal Santo, L. (2015). On the relationship between problem posing, problem solving, and creativity in the primary school. F. M. Singer, N. F. Ellerton, \& J. Cai (Eds), In Mathematical Problem Posing (pp. 103-123). New York: Springer.

Bunar, N. (2011). Altıncı Sınıf Öğrencilerinin Kümeler, Kesirler ve Dört İşlem Konularında Problem Kurma ve Çözme Becerileri. Yüksek Lisans Tezi, Afyon Kocatepe Üniversitesi Sosyal Bilimler Enstitüsü, Afyonkarahisar. 
Cankoy, O., \& Darbaz, S. (2010). Problem Kurma Temelli Problem Çözme Öğretiminin Problemi Anlama Başarısına Etkisi. Hacettepe Üniversitesi Eğitim Fakültesi Dergisi, 38, 11-24.

Çarkcı, İ. (2016). İlkokul 4. sınıf ögrencilerinin farklı problem kurma durumlarına yönelik ortaya koydukları problemlerin incelenmesi. (Yayınlanmamış yüksek lisans tezi). Gazi Üniversitesi, Ankara.

Çelik, A. (2010) İlköğretim Öğrencilerinin Orantısal Akıl Yürütme Becerileri ile Problem Kurma Becerileri Arasındaki İlişki. Yüksek lisans tezi, Hacettepe Üniversitesi, Ankara.

Çetinkaya, A. (2017). İlköğretim 8. Sinıf öğrencilerinin problem kurma becerilerinin incelenmesi. (Yayımlanmamış yüksek lisans tezi). Erciyes Üniversitesi Eğitim Bilimleri Enstitüsü, Kayseri.

Christou, C., Mousoulides, N., Pittalis, M., Pitta-Pantazi, D., \& Sriraman, B. (2005). An empirical taxonomy of problem posing processes. Zdm, 37(3), 149-158.

Cırıtçı, H., Gönen, İ., Kavas, D., Özarslan, M., Pekcan, N., \& Şahin, M. (2017). Ortaokul matematik ders kitabı 5. İstanbul: Bilnet Matbaacılık.

Çomarlı, S.K. (2018). Ortaokul matematik öğretmenlerinin veri işleme öğrenme alanına ilişkin problem kurma becerilerinin incelenmesi (Yayınlanmamış yüksek lisans tezi). Bartın Üniversitesi, Bartın.

Dede, Y., \& Yaman, S. (2005). Matematik öğretmen adaylarının matematiksel problem kurma ve problem çözme becerilerinin belirlenmesi. Eurasian Journal of Educational Research (EJER), (18), 41-56.

Dickerson, V. M. (1999). The impact of problem posing instruction on the mathematical problem solving achievement of seventh graders (Unpublished doctoral dissertation). Emory University, Atlanta, GA.

Dinç, B. (2018). Yedinci sınıf ögrencilerinin gerçek yaşam durumlarına uygun problem kurma becerilerinin incelenmesi (Yayınlanmamış yüksek lisans tezi). Eskişehir Osmangazi Üniversitesi, Eskişehir.

Ekici, D. (2016). Ortaokul öğrencilerinin problem kurma stratejilerinin belirlenmesi (Yayımlanmamış Yüksek Lisans Tezi). Dokuz Eylül Üniversitesi, İzmir. 
English, L. D. (1998). Children's problem posing within formal and informal contexts. Journal for Research in Mathematics Education, 29(1), 83-106.

Ev Çimen, E., \& Yıldız, Ş. (2017). A Review of Problem Posing Activities in Secondary School Mathematics Textbooks. Turkish Journal of Computer and Mathematics Education (TURCOMAT), 8 (3), 378-407.

Fidan, S. (2008). Illköğretim 5. sinıf matematik dersinde öğrencilerin problem kurma çalışmalarının problem çözme başarısına etkisi (Yayınlanmamış yüksek lisans tezi). Gazi Üniversitesi, Ankara.

Geçici, M.E., \& Aydın, M. (2019). Sekizinci sınıf öğrencilerinin geometri problemi kurma becerileri ile geometri öz-yeterlik inançları arasındaki ilişkinin incelenmesi. Kuramsal Ĕ̌itimbilim Dergisi, 12(2), 431-456.

Gizem-Karaaslan, K. (2018). Problem kurma yaklaşımıyla desteklenen bir matematik sinıfinda ögrencilerin cebir ögrenmelerinin ve problem kurma becerilerinin incelenmesi (Yayınlanmamış doktora lisans tezi). Hacettepe Üniversitesi, Ankara.

Gonzales, N. A. (1998). A blueprint for problem posing. School Science \& Mathematics, 98(8), 448-456.

Güzel, R. (2017). Eşitsizlikler konusunun öğretiminde problem kurma yaklaşımının akademik başarıya etkisi (Yayınlanmamış yüksek lisans tezi). Kastamonu Üniversitesi, Kastamonu.

Haylock, D., \& Cockburn, A. (2014). Küçük çocuklar için matematiği anlama (Çev. Ed. Zuhal Y1lmaz). Ankara: Nobel Yayınevi.

Holmes, E.E. (1995). New Directions in Elementary School Mathematics: Interactive Teaching And Learning. Englewood Cliffs, N.J. : Merrill.

Işık, C., \& Kar, T. (2015). Altıncı sınıf öğrencilerinin kesirlerle ilgili açık-uçlu sözel hikâyeye yönelik kurdukları problemlerin incelenmesi. Turkish Journal of Computer and Mathematic Education (TURCOMAT), 6(2), 230-249.

Kalaycı Y. (2014). Illkokul-ortaokul matematik ders ve öğrenci çalışma kitaplarındaki problem kurma etkinliklerinin incelenmesi ve problem kurmaya yönelik ögretmen görüşlerinin belirlenmesi (Yayınlanmamış yüksek lisans tezi). Atatürk Üniversitesi, Erzurum. 
Kaleli Yılmaz, G. (2015). Durum çalışması. Mustafa Metin (Ed.). Kuramdan uygulamaya eğitimde bilimsel araştırma yöntemleri içinde (s. 261-285). Ankara: Pegem Akademi.

Kanbur, B. (2017). İlköğretim matematik ögrretmen adaylarının dinamik geometri yazılımı ile desteklenmiş ortamda problem kurma durumlarının ve görüşlerinin incelenmesi (Yayınlanmamış yüksek lisans tezi). Gazi Üniversitesi, Ankara.

Kar, T. (2014). Ortaokul matematik öğretmenlerinin öğretim için matematiksel bilgisinin problem kurma bağlamında incelenmesi: kesirlerle toplama işlemi örneği (Yayımlanmamış doktora tezi). Atatürk Üniversitesi Eğitim Bilimleri Enstitüsü, Erzurum.

Kılıç, Ç. (2013). İlköğretim öğrencilerinin doğal sayılarla dört işlem gerektiren problem kurma etkinliklerindeki performanslarının belirlenmesi. Dicle Üniversitesi Ziya Gökalp Eğitim Fakültesi Dergisi, 20, 256-274.

Kılıç, Ç., \& İncikabı, L. (2013). Öğretmenlerin problem kurma ile ilgili öz-yeterlik inançlarının belirlenmesine yönelik ölçek geliştirme çalışması. Dumlupınar Üniversitesi Sosyal Bilimler Dergisi, 35, 223-234.

Kinach, B. M. (2002). A cognitive strategy for developing pedagogical content knowledge in the secondary mathematics methods course: Toward a model of effective practice. Teaching and Teacher Education,18, 51-71.

Knott, L. (2010). Problem posing from the foundations of mathematics. TMME, 7, 413-432.

Kojima, K., \& Miwa, K. (2008). A system that facilitates diverse thinking in problem posing. International Journal of Artificial Intelligence in Education, 18(3), 209-236.

Kurt, V. (2015). Problem kurma çalışmalarının 6.sınıf öğrencilerinin matematik kavramlarını öğrenme düzeylerine etkisi (Yayınlanmamış yüksek lisans tezi). Marmara Üniversitesi, İstanbul.

Lin, P. J. (2004). Supporting Teachers on Designing Problem-Posing Tasks as a Tool of Assessment to Understand Students' Mathematical Learning. International Group for the Psychology of Mathematics Education. Taiwan 
Ma, L. (2010). Knowing and teaching elementary mathematics: Teachers' understanding of fundamental mathematics in China and the United States. Newyork, NJ: Lawrence Erlbaum Associates.

Merriam, S.B. (2013). Nitel araştırma desen ve uygulama için bir rehber. (Çev. Ed. S. Turan). Ankara: Nobel Akademik Yayıncılık.

Miles, B.M., \& Huberman, M.A. (1994). Qualitative data analysis. London: Sage Publication.

Milli Eğitim Bakanlığı [MEB] (2017). Ortaokul matematik dersi (5, 6, 7 ve 8. sinıflar) öğretim programı. Ankara: Milli Eğitim Bakanlığı.

Milli Eğitim Bakanlığı [MEB] (2018). Ortaokul matematik dersi (5, 6, 7 ve 8. sinıflar) öğretim programı. Ankara: Milli Eğitim Bakanlığı.

Ngah, N., Ismail, Z., Tasir, Z., \& Mohamad Said, M. N. H. (2016). Students’ ability in free, semi-structured and structured problem posing situations. Advanced Science Letters, 22(12), 4205-4208.

Nixon-Ponder, S. (1995). Using Problem Posing Dialogue in Adult Literacy Education. Teacher To Teacher. Adult Learning, 7(2), 10-2.

Olkun, S., \& Toluk, Z. (2014). İlköğretimde Etkinlik Temelli Matematik Öğretimi. Ankara: Eğiten Kitap.

Onkun-Özgür, E. (2018). Yedinci sınıf ögrencilerinin sütun ve daire grafiğine uygun problem kurma becerilerinin incelenmesi (Yayınlanmamış yüksek lisans tezi). Eskişehir Osmangazi Üniversitesi, Eskişehir.

Özgen, K., Aydın, M., Geçici, M. E., \& Bayram, B. (2017). Sekizinci sınıf öğrencilerinin problem kurma becerilerinin bazı değişkenler açısından incelenmesi. Türk Bilgisayar ve Matematik Ĕgitimi Dergisi, 8(2), 218-243.

Patton, M.Q. (2014). Nitel araştırma ve değerlendirme yöntemleri. (Çev. Ed. M. Bütün ve S. B. Demir). Ankara: Pegem Akademi.

Polya, G. (1945). How to solve it: A new aspect of mathematical model. Princeton, New Jersey. 
Şahal, M. (2016). Problem kurma yaklaşımı ile işlenen tam sayılar konusunun öğrencilerin akademik başarısına ve matematik tutumlarına etkisi (Yayınlanmamış yüksek lisans tezi). Marmara Üniversitesi, İstanbul.

Salman, E. (2012). İlköğretim matematik öğretiminde problem kurma çalışmalarının öğrencilerin problem çözme başarısına ve tutumlarına etkisi (Yayınlanmamış yüksek lisans tezi). Erzincan Üniversitesi, Erzincan.

Say1, M.Ş. (2018). Ortaokul öğrencilerinin problem kurma becerileri ile cebirsel düşünme düzeyleri arasindaki ilişki (Yayınlanmamış yüksek lisans tezi). Necmettin Erbakan Üniversitesi, Konya.

Schoenfeld, A. H. (1991). What's all the fuss about problem solving? Zentrallblatt fur Didaktik der Mathematik (ZDM), Vol23(1), 4-8.

Semizoğlu, R. (2013). İlköğretim 5. Sinıf Öğrencilerinin Okuduğunu Anlama ve Görsel Okuma Düzeyi ile Problem Kurma Becerisi Arasındaki İlişkinin İncelenmesi. Yüksek Lisans Tezi, Gazi Üniversitesi Eğitim Bilimleri Enstitüsü, Ankara.

Sezgin, E. (2011). Problem Çözme Becerisi Ölçeğinin Geliştirilmesi. Yüksek Lisans Tezi, Ankara Üniversitesi, Ankara.

Silver, E., \& Cai, J. (1996). An analysis of aritmetic problem posing by middle school students. Journal for Research in Mathematical Research,27(5), 521-539.

Silver, E., \& Cai, J. (2005). Assessing students’ mathematical problem Posing. Teaching Children Mathematics, 12(3), 129-135.

Silver, E.A. (1994). On Mathematical Problem Posing. For the Learning of Mathematics, 14(1), 19-28.

Souviney, R. J. (1994). Learning To Teach Mathematics (2nd Ed.). Englewood Cliffs: Macmillan Publishing Company.

Stoyanova, E. (1998). Problem posing in mathematics classrooms. In A. McIntosh, and N. Ellerton (Eds.), Research in mathematics education: A contemporary perspective (pp.164-185). Perth: MASTEC Publication.

Stoyanova, E. (2003). Extending Students' Understanding of Mathematics via ProblemPosing. Australian Mathematics Teacher, 2, 32-40. 
Stoyanova, E., \& Ellerton, N. F. (1996). A framework for research into students' problem posing. In P. Clarkson (Ed.), Technology in Mathematics Education, (pp. 518-525). Melbourne: Mathematics Education Research Group of Australasia.

Tertemiz, N.I. (2017). İlkokul öğrencilerinin dört işlem becerisine dayalı kurdukları problemlerin incelenmesi. Türk Ĕ̈itim Bilimleri Dergisi, 15(1), 1-25.

Tichá M., \& Hošpesová, A. (2009). Problem posing and development of pedagogical content knowledge in pre-service teacher training. CERME 6, Lyon, France. (1941-1950).

Toluk-Uçar, Z. (2009). Developing pre-service teachers understanding of fractions through problem posing. Teaching and Teacher Education, 25(1), 166-175.

Turhan-Türkkan, B. (2017). Sosyomatematiksel konularla bütünleştirilmiş matematik öğretimi: sosyal adalet ve eşitlik değerlerine ilişkin farkindalık ile problem kurma becerisi geliştirmeye yönelik bir eylem araştırması. (Yayımlanmamış doktora tezi), Çukurova Üniversitesi, Sosyal Bilimler Enstitüsü, Adana.

Türk Dil Kurumu [TDK]. (2015). Türkçe Sözlük. Ankara: Türk Dil Kurumu Yayınları

Türnüklü, E., Ergin, A.S., \& Aydoğdu, M. Z. (2017). 8. sınıf öğrencilerinin üçgenler konusunda problem kurma çalışmalarının incelenmesi. Bayburt Eğitim Fakültesi Dergisi, 12(24), 467-486.

Türnüklü, E.B., \& Yeşildere, S. (2005). Problem, problem çözme ve eleştirel düşünme. Gazi Üniversitesi Gazi Eğitim Fakültesi Dergisi, 25(3), 107-123.

Van de Walle, J. A., Karp, K. S., \& Bay-Williams, J. M. (2013). Illkokul ve ortaokul matematiği: Gelişimsel yaklaşımla ögretim (S. Durmuş, Çev. Ed.). Ankara: Nobel Akademik Yayıncılık.

Yalçın, A.İ. (2017). Matematiksel problem kurma stratejilerinin 5. sınıf öğrencilerinin problem kurma başarılarına etkisi (Yayınlanmamış yüksek lisans tezi). Gazi Üniversitesi, Ankara.

Yıldırım, A. ve Şimşek, H. (2011). Sosyal bilimlerde nitel araştırma yöntemleri. (8. baskı). Ankara: Seçkin Yayıncılık. 
Yıldız, Z. (2014). Matematikte problem kurma çalışmalarının ögretmen adaylarının problem kurma becerilerine ve üstbilişsel farkındalık düzeylerine etkisi (Yayınlanmamış doktora tezi). Marmara Üniversitesi, İstanbul.

\section{Summary}

\section{Purpose and Significance}

People have faced various problems that they need to solve throughout history and sought to find solutions. Although the problems people have experienced are mostly similar, they have also shown a difference from society to society and individual to individual. It is possible to say that the lives of individuals who can solve their problems will be easier. Accordingly, the problem-solving skill is not only a means of success in math class but also one of the important tools to succeed in everyday life. Mathematics education researchers have defined the concept of problem-posing in different ways. Problem posing in the definitions: Creating new problems from a given situation/problem (Akay, 2006; Dede and Yaman, 2005; Silver, 1994; Tichá and Hošpesová, 2009) or generating problems by making changes to the given situation/problem (Akay, Soybaş and Argün, 2006; Dinç, 2018; Silver, 1994; Tichá and Hošpesová, 2009). Problem posing, which is closely related to problem solving, is a further step in solving problems and includes problem solving (Bonotto and Dal Santo, 2015). It requires a more complex and high-level thinking skill than the problem solving (Bunar, 2011). In studies on middle school students who constitute the research group of this study, determination of the skills of the students' problem-posing (Cetinkaya, 2017; Dinç, 2018; Ekici, 2016), the relationship of problem-posing skills with other skills and psychological structures (Çelik, 2010; Geçici and Aydın, 2019) and the results of the instruction using the problem-posing approach (Fidan, 2008; Kurt, 2015; Şahal, 2016) studies were performed. It has emerged that middle school students do not have a study in which detailed research of the problem-posing skills of the multiplication and division operations. For this reason, it can be said that middle school students need to be explained by detailed investigations of the difficulties identified in the problems of multiplication and division. The results from the stidies on the source of this difficulties can help to increase the quality of the instruction to be made. It can reveal the wrong perceptions of students for multiplication and division. The aim of this study is to determine the difficulties in the multiplication and division of middle 
school students and to explain the problems identified in detail. To achieve this goal, the following research questions have been sought for answers.

1. What kind of problems were posed by students in multiplication and division operations?

2. What kind of meanings did students load to the multiplication and division operations?

\section{Method}

The research group of the study consisted of a total of 95 fifth-year students studying in the state middle school of a province in the Eastern Anatolia Region of Turkey in 2017-2018 academic year. Research is an example of a case study in which the qualitative research approach is adopted. The data of the study was derived from the structured problems that students have posed for multiplication and division and semi-structured interviews with 12 students. The data obtained from the study was analyzed with the help of content analysis. In the study of the resulting categories, researchers evaluated as partners. They provided a consensus among researchers about the compliance of the categories with data. An external specialist was used for the reliability of data analysis. The specialist was a mathematics teacher with a $\mathrm{PhD}$ thesis in elementary mathematics education, which have served as a state middle school. The categories and students' expressions provided the categories were presented to the expert. The expert evaluated the data according to their compatibility with the categories. The expert confirmed that the data obtained from the study were compatible with the categories.

\section{Results}

It was emerged that most of the students generated appropriate problems for the specified multiplication operation. According to this, most of the students were successful in posing a problem with the multiplication operation. As a result of the studies, it was found that half of the students could pose mathematically appropriate problems, while the other half were unsuccessful. Accordingly, it was determined that students more failed to pose problems with the division than multiplication. When examining the structures of the students' mathematical appropriate problems, most of the students posed problems with the scale and repetitive addition structures in multiplication operation, respectively. In the division operation, 
students were determined to consider the most equal sharing structure. When evaluating problems that were posed by students but were not suitable for multiplication and division, it was revealed that students generated problems with the most practice, not real-life problems. Moreover, students also posed problems with other operations, problems without using question phrase and problems unrelated to given operations. Especially in the division operation, some of the students were reflected in the concept of equal sharing problems. Some students posed problems with missing, excess, or unequal sharing rather than equal share. It was possible to say that most of the students interviewed were in an understanding of real-life disjointed, transactional characteristics that were not suitable for the conceptual meaning of the operation involved in multiplication and division. It was thought that students had a real-life disjointed understanding of the multiplication and division operations, which was reflected in the difficulties of students’ problem-posing activities.

\section{Discussion and Conclusion}

The source of the difficulty of practice writing, most common difficulty found in the study, was not establishing relationship between operations and real life. The result of this study brought to mind the criticism of Schoenfeld (1991). Schoenfeld (1991) stated that in schools, students ignored their realistic thinking when solving problems and did not associate mathematics with real life. One of the objectives of mathematics education is to use mathematics in daily life and other areas (Dinç, 2018). For this reason, teachers need to use instructional approaches to emphasize the nature, structure and connection of real life to multiplication and division operations. It will be beneficial for teachers to concentrate more on the examples associated with their real lives during the introduction of the structures of the processes. In this way, it can be useful for students to develop an accurate understanding of the operations. 